\title{
Remembrance (Zikr) Approach to Treat Drug Addiction Problems
}

\author{
Muhammad, N. H. N, Omar, S.H.S
}

To Link this Article: http://dx.doi.org/10.6007/IJARBSS/v9-i7/6215

DOI: $10.6007 /$ IJARBSS/v9-i7/6215

Received: 01 May 2019, Revised: 11 June 2019, Accepted: 30 June 2019

Published Online: 04 July 2019

In-Text Citation: (Muhammad \& Omar, 2019)

To Cite this Article: Muhammad, N. H. N., \& Omar, S. H. . (2019). Remembrance (Zikr) Approach to Treat Drug Addiction Problems. International Journal of Academic Research in Business and Social Sciences, 9(7), 10701080.

Copyright: (C) 2019 The Author(s)

Published by Human Resource Management Academic Research Society (www.hrmars.com)

This article is published under the Creative Commons Attribution (CC BY 4.0) license. Anyone may reproduce, distribute, translate and create derivative works of this article (for both commercial and non-commercial purposes), subject to full attribution to the original publication and authors. The full terms of this license may be seen

at: http://creativecommons.org/licences/by/4.0/legalcode

Vol. 9, No. 7, 2019, Pg. $1070-1080$

Full Terms \& Conditions of access and use can be found at http://hrmars.com/index.php/pages/detail/publication-ethics 


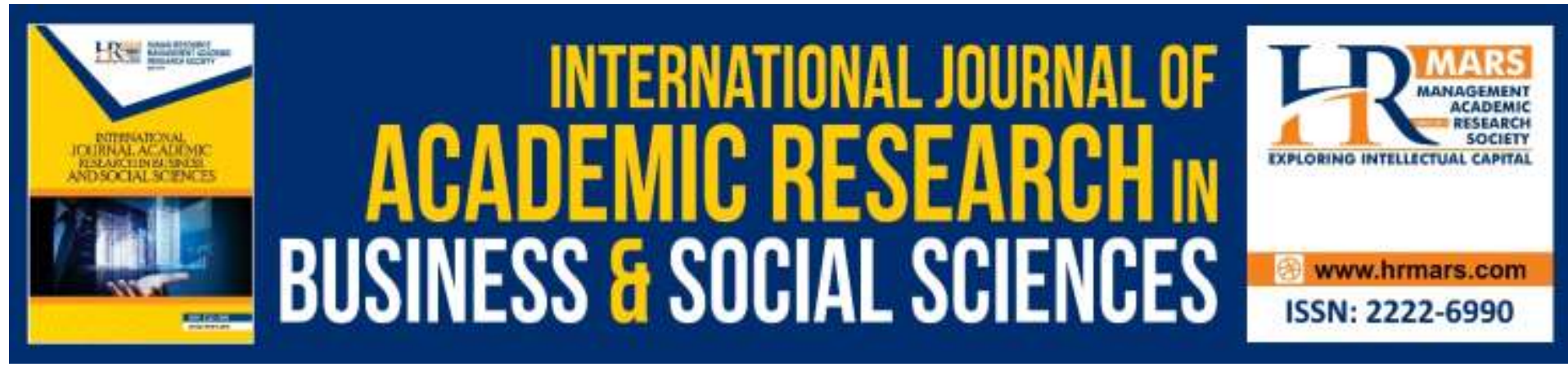

\title{
Remembrance (Zikr) Approach to Treat Drug Addiction Problems
}

\author{
${ }^{1}$ Muhammad, N. H. N., ${ }^{2,3}$ Omar, S.H.S. \\ ${ }^{1}$ Faculty Contemporary Islam, ${ }^{2}$ Institute of Product Research and Islamic Civilization \\ (INSPIRE), University Sultan Zainal Abidin, Campus Gong Badak, ${ }^{3}$ Centre for Research in \\ Addiction (CENTRENA) University Sultan Zainal Abidin, Campus Gong Badak, 21030 Kuala \\ Terengganu, Terengganu, Malaysia
}

\begin{abstract}
The issue of drug addiction is the most common symptom of society's disease right now. The problem of drug addiction has hit all walks of life, especially young people. Drugs undermine economy power and undermine national development by poisoning the minds and spirits of individuals to adapt to current needs and challenges. Drugs can be considered the root cause of all kinds of crime, the evils of domestic, community and national unrest. This is due to the lack of Islamic spiritual values in the addict. This problem is due to the ignorance of Islam and the lack of spiritual appreciation in daily life. This study aims to identify a remembrance approach to treat drug addiction problems at the "Rumah Penawar Drugs Rehabilitation Treatment Center Puncak Alam" to ensure long-term and ongoing recovery. This study is qualitative. The data were collected using the design of interview techniques and document analysis by examining aspects of remembrance and their role and finding them in accordance with the Quran and al-Sunnah. Interviews were conducted with the management of the "Rumah Penawar Drugs Rehabilitation Treatment Center Puncak Alam" and among the trainees. The data obtained were analyzed descriptively. The study found that there are 7 types of spiritual practices practiced at the "Rumah Penawar Drugs Rehabilitation Treatment Center Puncak Alam". Such practices include remembrance, prayers, and recitation of the Quran, fasting, other circumcision practices, recitation and prayer with teachers. Remembrance elements play a vital role in preventing individuals from getting into drug abuse. Remembrance is one of the greatest spiritual powers of Islam. There is no single worship in Islam that is separate from remembrance. Even the prayer spirit that is the pillar of religion is remembrance (zikrullah). The study concludes that remembrance and other spiritual practices practiced at the "Rumah Penawar Drugs Rehabilitation Treatment Center Puncak Alam" on a regular basis can have a positive effect especially in the treatment and recovery of drug addiction and the personal development of trainees. A good appreciation of spiritual values such as remembrance in life can avoid negative elements, especially drug abuse. Formerly drug addicts are also capable of being good leaders in the future.
\end{abstract}

Keywords: Remembrance, Recovery Treatment, Drug Addiction. 


\section{Introduction}

Islam is fundamental to human life. Islam is a religion that emphasizes the sanctity of the soul in civilized human life. The purity of the soul is part of the faith that produces the individual who obeys the Islamic law (Ghani, 2014). Therefore, Islam is very important in everyday or in daily life as it can protect people from problems that exist especially drug problem. The issue of drug addiction is seen as very serious lately around the world (Ghani, 2014). If the problem of drug addiction is not solved, it can create more problem and troubled communities and countries.

The problem of drug addiction has hit all walks of life, especially young people. Drugs undermine economic power and undermine national development by poisoning the minds and spirits of individuals to adapt to current needs and challenges. Drugs can be considered the root cause of all kinds of crimes such as robbery, theft, extortion and other crimes that are causing havoc in the household, society and country. In addition, drug addicts are a burden to the country. The government has to spend millions of dollars a year to cover rehabilitation centers. In addition, there are distributors who reap the benefits of double the suffering of loyal addicts (Noor \& Ghazali, 2010).

From time immemorial, Muslims have been barred from drinking intoxicating substances. Islam forbids anything intoxicating for the purpose of maintaining the mind, the health of the body and protecting the individual and the whole community. In other words, Islam forbids drunkenness because of the harm it causes. This harm involves the addict in his mind, his body, the waste of property and the ruin of family relations and the neglect of religious orders. It is not confined to itself but is detrimental to society and the whole of humanity (Noor \& Ghazali, 2010).

Today, drug rehabilitation is a challenge for scientists, especially psychologists, psychiatrists and social workers. Various approaches have been tried such as substitution therapy, military training, homeopathy, behavioral modification, psychological rehabilitation, psychotherapy and many other endeavors. However, it can be said that no one has been fully recognized to achieve an overall recovery from billing symptoms. The government in particular is working to address this issue, but to date there have been no positive signs of a decrease in billing issues (Adam, 2014).

In this regard, the study was conducted to identify a remembrance approach to treating drug overdose problems at the "Rumah Penawar Drugs Rehabilitation Treatment Center Puncak Alam" to ensure long-term and sustained recovery. The study area and the respondents used in this study were the residents of the "Rumah Penawar Drugs Rehabilitation Treatment Center Puncak Alam". Therefore, this study is to identify a comprehensive spiritual recovery approach to address the problem.

Spirituality is a must in everyday and daily life. As a Muslim individual, spirituality is very important in life. Spirituality can be practiced through its practices. However, if spiritual practices are not well-practiced, they can have a negative effect on individuals especially for drug treatment recovery (Ismail \& Omar, 2017). This clearly shows that the religious element referring to spirituality is very much needed to be studied and appreciated. According to Suhid 
(2005), people who have religious values in themselves can refrain from doing anything that is bad and contrary to Islam.

The effort to recover a drug addict is not just a treatment and recovery process but should be followed by a mentorship program after leaving the rehabilitation center. The public should be aware of the drug-free recovery process largely depending on the consciousness of the addict, as well as the caring attitude, spiritual recovery approach, community trust and support and the role of the former drug addict himself (Adam, 2014). Therefore, the key ingredient in recovery is the drug addict's self-awareness that creates a high spiritual value that leads to conviction. As Allah Almighty says, "Allah does not change the condition of a people until they change their situation" (Surah al-Ra'd: 11). This study also examines the experiences and learning of former addicts in raising and generating awareness and selfconfidence based on knowledge, influence, appreciation and spiritual practice to be free from the influence of drugs.

At the "Rumah Penawar Drugs Rehabilitation Treatment Center Puncak Alam" for example, there are a number of things that can be considered an advantage and one that should be noted is the ability of a former addict to carry out a rehabilitation treatment program using understanding, enhancement and appreciation of spiritual practices such as remembrance, prayer, recitation of the Quran, fasting, other practices of circumcision, recitation and ta'lim with teachers such as the ceremonies with recitation of hadiths and scholarly books. In addition, continuous involvement with local community communities such as congregation prayers and tazkirah programs. This can control the desire for drug addiction. Thus, this article can provide insights into the concept of remembrance for the treatment and recovery of drug addicts from an Islamic perspective through spiritual approaches to reducing drug addiction cases while increasing the knowledge of the community.

\section{The Elements of Spirituality in the Quran and Al-Sunnah}

Islamic-based drug rehabilitation treatment is carried out by government and private drug rehabilitation treatment centers. However, as a result of the findings, the private sector or Non-Government Organization has largely adopted this method of treatment by obtaining a promising recovery (Ghani, 2014). This remedial treatment utilizes a spiritual approach using remembrance, prayer, guidance and recitation of the Quran, fardhu 'ain, fasting, other circumcision practices, meditation and prayer with teachers. This remedial treatment is based on the Quran and hadith by incorporating the method of Sufism (Ghani, 2014). This is further reinforced by the message of Allah Almighty, which means: "And we derive from the Quran the healing and mercy of the believers" (Surah al-Isra ': 82). In a hadith narrated by Saidina Ali bin Abi Talib R.A., the Prophet Muhammad S.A.W. It said: "The best medicine is the Quran". Allah S.W.T. said, that is, "And we gradually bring down the Qur'anic verses that are a cure and a mercy for those who believe in Him" (Surah al-Isra': 82).

The spiritual approach used in Islam is seen as a return to the nature of human creation. Spiritual illness cannot be treated with the injection of medicine, not with violence and power but with spiritual guidance. According to the scholars of Sufism, evil cannot be abolished with a sword. Evil can only be eliminated by repentance and the Quran shows that human illness is his sin and his remedy is repentance. Therefore, the treatment of spiritual drug 
rehabilitation is the best way to address the problem of drug addiction facing the world (Ghani, 2014).

\section{Spirituality is Therapy to Treating Drug Addiction}

Various scientific methods are used but psychiatric treatment through Islamic Psycho spiritual Therapy is undeniable. A combination of biological, social, psychological and religious treatments should be the top choice for all drug rehabilitation and drug treatment centers in the treatment of internal illnesses. This is because drug abuse is not considered a physical issue, it is a spiritual disease. Therefore, the problem of drug addiction cannot be solved by injection, but rather by spiritual guidance (Mohd, 2013).

Islamic Psycho spiritual Therapy means a method of psychiatric and spiritual treatment based on Islamic sources and Islamic practices that do not conflict with Shari'ah principles. The goal is to give birth to self, soul and spirit. The therapy complies with the original nature of human creation because it is a God-given treatment as the Creator of all beings including humans (Mohd, 2013).

According to Mohd, 2013, there are six fundamentals of Islamic-based drug rehabilitation:

1) Believe that the principle of piety is a form of treatment

2) Worship is a form of treatment

3) Patience is the path to recovery

4) Remembrance as a treatment

5) Be sure to repent of the medical tract

6) Respect and reasoning

The source of Quranic and al-Sunnah treatment is appropriate in treating the spiritual and psychological condition of the human being apart from the belief that only God can best solve human problems. This method basically emphasizes prevention better than treating and this can be achieved if a servant really has a good understanding of the concept of devotion and submission to Allah Almighty. Therefore, three things one must know, first of all is the knowledge of God, the ability to recognize the great essence of spirituality and to give up the true nature of spirituality. In the early stages, an individual needs to rely on the mentor, especially if the individual is able to perform the treatment with his or her own strengths. This is because the method actually requires a person to realize the potential of self-perfection that he or she can only achieve. This method of therapy actually places the actual diagnosis of an individual on the spiritual aspect rather than on the physiology. This therapy is believed to be a powerful fortress and a source of spiritual and spiritual enrichment for addicts. As long as one commits himself to Allah, with His permission is protected from all forms of suspicion and evil (Mohd, 2013).

According to Ibrahim, 2018 principal at "Rumah Penawar Drugs Rehabilitation Treatment Center Puncak Alam" said that religion is the best way to solve all the problems especially drug addiction problem. There are consist with three method which is method of think, method of practices and method of knowledge. The trainers will be guidance is based on the practice of Basmalah, on the basis of Faith, Islam and Ethics. The program is based on surahs in the Quran and the Prophet's history, Companions and Past Scholars, emphasizing the 
practice of Sunnah and Siasah. The program, carried out not only to treat drug addiction, but also to help create a culture of healthy living and blessed by Allah S.W.T. They practiced method of think means repentance return to God (tawakal to Allah S.T.W) and come out with thought the history of the prophet's and the messenger of God (sirah prophet) to create the desire of good practices (they called method of practices ('amal). After that the trainers will be follow the remembrance (zikr) as a spirituality treatment and practiced in daily life. The remembrance (zikr) is necessary practices in their life. They also apply the nature of the prophet Muhammad S.A.W it is true, honest, spread, tactful (siddiq, amanah, tabligh, fatonah) in daily life and they practiced about five pillars of Islam and six pillars of faith (method of knowledge). The trainers will be guide to be a grateful, patient to God and be blessed to Allah S.W.T.

\section{Remembrance (Zikr) Practice is One of Treatment for Drug Addiction}

Remembrance is a practice practiced in Islam. The command to perform the remembrance is found in the Quran and al-Sunnah. Remembrance is a practice which is commanded to be multiplied without any restrictions and conditions to practice such as other worship such as prayer, fasting and so on. The Word of Allah S.W.T, which means: "O you who believe, remember Allah with a great memory" "and praise him morning and evening" (Surah alAhzab: 41-42). Based on the verse, the scholars commented that the commandment to remember and remember Allah S.W.T has its own uniqueness and privilege compared to His other commandments. The commandments of remembering and remembering Allah S.W.T are not limited to a certain number such as the order of prayer. Commemorating and remembering Allah S.W.T is not specific to its execution at certain times such as the orders of prayer, fasting, charity and pilgrimage. Instead, the order of remembering and remembering Allah Almighty is in abundance, morning and evening with hearts, tongues and even members. The commandment to remember and remember Allah S.W.T also needs to be performed either individually or in groups, silently or loudly and in mosques or elsewhere. Remembrance is the secret and the direct link between the servant and his Lord. Every believer who remembers Allah must be remembered by Him (Al-Merbawi, 2010).

Remembering in terms of language means to speak and remember. From the standpoint of the term Sufism, remembrance means escaping forgetfulness and forgetfulness by always being present with God. Remembrance refers to the memory and presence of a strong heart, a continuation of the meaning of the divine until the oblivion is removed from the heart. In addition, remembrance also means repeating the words of God heartily and verbally, or repeating the pronunciation and remembering of a character, law, deed, or thing that may bring us closer to Allah S.W.T (Al-Merbawi, 2010).

Remembrance is divided into two types which is general remembrance and special remembrance. Common remembrance is a remembrance of other religious acts such as prayer and so on which all practices are performed in remembrance of God. This remembrance is performed on its own when the practice is performed with openness (JAIS, 2012).

While special remembrance is the mention and remembrance of God. The Qur'an and the alSunnah have mentioned several major types of special remembrance which is zikrullah, 
tafakur, tasbih, tahmid, tahlil, takbir, al-asma 'al-husna, and recitation of the Qur'an. This remembrance may be practiced at any time and in the place of a person except where it is prohibited. Remembering this is what needs to be increased. In addition, there are remembrances related to specific times, places, and circumstances. This kind of remembrance is also good to practice. Scholars have authored and compiled numerous works to illustrate this practice of remembrance which can be referred to (JAIS, 2012). Therefore, it is important for the practice of remembrance to be based on the knowledge, understanding and determination to bring the heart and life to it. The deeper the knowledge of remembrance matters, the higher level of desire and determination to perform and live it, the more effective it becomes to the heart.

There are also remembrances that require talqin, tarbiyah and secular rituals. This remembrance is called a Sufism zikr or the degree of remembrance. Remembrance can be practiced for those who wish to improve themselves, purify themselves, approach themselves, remove the spiritual hijab and thus achieve enlightenment, but should refer to a skilled and experienced member.

There are many types of remembrance which is beads, tahmid, takbir, tahlil, recitation of the Qur'an and so on, but the essence of all these types of remembrance is remembering Allah (zikrullah). Thus it can be said that remembrance consists of two things, namely verbal remembrance and remembrance with heart of God and matters connected with it. Memory is the essence of remembrance while it is the way of remembering it. The level of memory also varies so that some reach the point of forgetting something other than the memory and this is what the true remembrance. Regarding this fact of remembrance, al-Kalabadhi states that remembrance is something other than that which is remembered in the remembrance. In this case, al-Kalabadhi refers to the word of God, which means: "and remember your Lord when you forget" (Surah al-Kahf: 24). Al-Kalabadi comments on the above, if you forget something other than Allah, then you have remembered Allah when one forgets something other than Him (Al-Merbawi, 2010). Thus, remembrance is one of the spiritual approaches to the treatment of drug addiction. That means remember of Allah and forget drug and evil.

One does not reach the level of remembering God with so much memory that he remembers God in all situations and that is a level in which remembrance is made perfect in himself. On this point Ibn 'Abbas explained that the great remembrance was the one who remembered Allah after the prayer, morning and evening, and after he had risen from his sleep, every time he went out morning and evening from his house he remembered Allah. A person is not considered a person who remembers Allah S.W.T until he remembers Allah S.W.T while standing, sitting, and lying down. This is not achieved in the blink of an eye, remembering the need for training and mentoring in order to achieve it easily, quickly and effectively (AlMerbawi, 2010).

This can help drug addicts overcome the problem of drug addiction by constantly meditating and getting closer to Allah S.W.T. When the mind and heart are always focused on remembering Allah S.W.T only, directly it can help the drug addict forget about it. This can reduce and prevent aggressive drug addicts and drug users. Therefore, early or late treatment with remembrance (zikr) treatment can help drug addicts get rid of drug addiction. 
The most enlightened person is the most important person in the presence of Allah S.W.T. Remembrance is one of the best, cleanest, and best practices of any human being in the sight of Allah S.W.T. In addition, remembrance is fundamental to the journey of drawing closer to God and achieving His pleasure as meditation can purify and purify the human heart and soul. Therefore, purification and purification of the heart should be given the same focus and importance as in the hadith of the Prophet Muhammad S.A.W said: "Know that in the human body there is a lump of blood, if it is good then the whole body is good, when it is broken then the whole body is damaged, know that it is the heart." Thus, remembrance is the practice of purification of the heart, the opening of the spiritual hijab, the strengthening of faith and piety, the abolition of hypocrisy, the eradication of passion, the suppression of evil interference and so on. According to the word of Allah S.W.T, it means: "(that is) the believers and their hearts are at rest in remembrance of Allah S.W.T. Remember, only by remembering God the heart is at peace" (Surah al-Ra'd: 28). The heart can achieve the essence of peace, tranquility, and happiness once it has been cleansed and purified and its diseases can be removed (Al-Merbawi, 2010). Therefore, remembrance (zikr) is a very effective practice in the treatment of drug addiction. Keeping your heart and spiritual mind calm and heart calm, then do not remember or addicted to drugs, directly forget and leave drug addiction.

Remembering and reading the Qur'an is a guiding light that illuminates the heart. With the enlightenment creation of the heart will removed the bad and disgusting character and nature, and the heart becomes clean and shining with the guidance of the spirit. The word of Allah S.W.T means: "be mindful of Allah and read His book, for it is a guide for you in this world and a fame for you in heaven". Thus, remembrance is also a cure for ailments of the liver which is the despicable nature that lies within it. In addition, remembering death and reading the Qur'an, which is also part of the remembrance, becomes a polish to the heart that is consumed with despair. The Prophet Muhammad S.A.W said, "To remember death and to read the Qur'an" (Al-Merbawi, 2010). Therefore, it is clear that remembrance (zikr) is a healer for the heart and a detractor of the despicable nature of the heart.

Remembrance also plays a role in awakening the default heart. It is because of those who have done evil, and remember God. Then experiences the consciousness of the soul and realizes its mistake, sin, shame and evil. This led him to repent and not continue or repeat his past mistakes. Allah Almighty says: "And those who, when they have done disgusting or selfabusive acts, remember Allah, they are constantly seeking forgiveness for their sins, and no one can forgive sins except Allah, and they do not continue what they have done, but they know it "(Surah al-'Imran: 135) (Al-Merbawi, 2010).

Obviously remembering has shown its effect and impact on people who commit sin and evil. In remembrance of God, one gains consciousness that motivates him to repent is and do not repeat again. Instead of those who do evil and do not remember God, they do not want to repent and turn to Him, because they do not feel the awareness of themselves and the sins they have committed. Therefore he continued to do evil, and he became part of the evildoers. The Word of Allah S.W.T, means: "And do not be like those who forget Allah, so He (Allah) forgets them for themselves, they are the killers" (Surah al-Hasyr: 19). Forgetting Allah makes one forget himself without remembering and realizing his guilt and continuing to sin without repentance until he becomes a murderer (Al-Merbawi, 2010). Whenever one 
becomes aware and repents to Allah S.W.T for past transgressions and evils and decides to abandon them and does not want to repeat them, it can indirectly help to cure and recover from drug addiction.

Remembrance plays a role in eliminating the impulse of self-indulgence that drives one to do things contrary to religious orders. This occurs when the remembrance becomes strong and manly, so the impulse to commit evil can be eradicated. Prophet Muhammad S.A.W. said: "Indeed the mufarridun group has gone ahead. Who is the mufarridun, O Messenger of Allah? He said: They are those who adhere to the zikrullah where the remembrance has placed (to relieve) their burden, and they will come on the Day of Judgment in a state of light". Regarding this hadith al-Dahlawi explains that when the light of remembrance (zikr) enter their minds (the mufarridun / those who keep in remembrance) and the concentration will show in their self and removed animal characteristic (the attributes of Allah's supremacy) is engraved in them, the virtues will be thwarted, their desire will be extinguished and their burden (in the hereafter) will be lost. The loss of their burden in the hereafter is due to the eradication of their desire to commit a person to commit a crime that he does not want to do (Al-Merbawi, 2010).

Remembrance also plays a role in stabilize and strengthening one's faith. This is because a person's faith can become dim if it is not renewed and strengthened. The strengthening of faith is to instill a sense of monotheism into the soul through the monotheistic path of monotheism. The Word of the Prophet Muhammad S.A.W. to friends, meaning: "Renew your faith. He asked: O Messenger of Allah, how can we renew our faith? He said: Make the most of La Ilaha Illallah" (Al-Merbawi, 2010).

Remembrance also plays a role in removing the spiritual hijab and opening the path of enlightenment. Saying, understanding, believing, and remembering the word monotheism in a state of sincerity led to the opening of the door of ma'rifat to the level of 'Arash. Prophet Muhammad S.A.W. said: "One does not call La llaha Illallah" in sincerity unless it is opened to him by the windows of heaven and leads to 'Arash as long as he abstains from great sins (AlMerbawi, 2010).

Thus, remembrance (zikr) is one of the spiritual approaches to the treatment and cure of drug addiction and can guarantee a sustained and lasting recovery with the permission of Allah S.W.T. This is because the practice of remembrance is the practice of purifying the soul and strengthening the faith and devotion to Allah S.W.T. Allah S.W.T. ordered us to carry out the zikrullah and the Prophet Muhammad S.A.W. has taught us how to implement it in the Quran and al-Sunnah of the Prophet Muhammad S.A.W and can refer to the interpretations and descriptions of the scholars. Thus, it is clear that the practice of remembrance is not only a worship, but also a practice that can purify the human soul strengthening their faith, come closer to Allah S.W.T, open the spiritual hijab and thus achieve enlightenment towards Him. Thus, the practice of remembrance (zikr) is the most effective and effective spiritual treatment for the problem of drug abuse. 


\section{Conclusion}

In a nutshell, strongly believe that remembrance (zikr) the power of spirituality in daily life Muslim person. According to this research, remembrance (zikr) can help people to solve the drug addiction problem. In addition can help society problem also. Each rehabilitation center has different recovery methods, but each has the same treatment method based on the Quran and the Sunnah. There are drug rehabilitation centers that have taken this approach to Islamic Psycho spiritual Therapy, either fully or partially, and have greatly impacted the spiritual development of these addicts. However serious research and refinement of this method needs to be made continuously and more integrated. In conclude, remembrance (zikr) is the best way to recovery treatment drug addiction in long time and also can reproduce humans who were once involved in social symptoms, to humans who can benefit or contribute to society and the country. It is an effort to encourage the community, especially the youth, to continue to do good things and to prevent harm. At "Rumah Penawar Drugs Rehabilitation Treatment Center Puncak Alam" had organize activities that are beneficial to society especially youth, so that time is not wasted on doing unhealthy activities or unwell symptoms. Fortunately, they also apply and inculcate the practice of love as a Muslim person and with passion to help each other in religion. It is can motivated their trainers to be more passion to become a better person and continually, feel appreciation, grateful, peace and happy in life journey.

\section{Acknowledgement}

This article is part of a research sponsored by the Center for Research and Innovation (CRIEM), Sultan Zainal Abidin University (UniSZA), Gong Badak Campus 21300 Kuala Nerus, Terengganu, Malaysia and UniSZA/NRGS/2013(RR057-1) grant from Malaysia Ministry of Higher Education.

\section{Corresponding Author}

Syed Hadzrullahtfi Syed Omar, Institute Of Islamic Product Research and Islamic Civilization (INSPIRE), Email: sylutfi@unisza.edu.my.

\section{References}

Al-Merbawi, M. A. M. (2010) Zikir Dan Perananya Dalam Pembentukan Sahsiah. Jabatan Usuluddin. Fakulti Pengajian Kontemporari Islam. Universiti Sultan Zainal Abidin.

Ghani, S. A., \& Adam, F. (2014). Pemulihan Dadah Menurut Persepktif Agama Di Malaysia (Drugs Abuse and Rehabilitation in Religion in Malaysia). Jurnal Hadhari: An International Journal, 6(1), 75-85.

Ghani, S. B. A., Rashidi, F., \& Wahab, B. (2014). Penilaian Penyalahgunaan Dadah Menurut Fatwa Ulama Dari Perspektif Islam. Journal of Business and Social Development, 2(1), 57-62.

Ibrahim, W. W. A. A. (2018) Interview Principal at "Rumah Penawar Drugs Rehabilitation Treatment Center Puncak Alam".

Ismail, N. N \& Omar, S. H. S. (2017), Kerohanian Islam:

Penghayatan dari Sudut Amalannya,

Proceeding of International of Conference of Empowering Islamic Civilization, Universiti Sultan Zainal Abidin. 
JAIS, (2012). Keperluan Zikir Dalam Kehidupan Seharian. Khutbah Jumaat 09 November. Jabatan Agama Islam Selangor. Retrieved google.

Mohd, M. D. M. R. (2013). Rawat Rohani Terapi Mujarab Penagih. Mega Agama.

Mohd, M. D. M. R., \& Jailani, A. B. B. O. (2015). Bab 11 Integrasi Terapi Psikospiritual Islam Dalam Modul Rawatan Dan Rehabilitasi Berasaskan Tc Therapeutic Community.

Noor, A. M., \& Ghazali, M. A. I. (2010). Penyalahgunaan Dadah Dan Kewajaran Peruntukan Hukuman Mati Ke Atas Pengedar Dadah Di Malaysia: Satu Analisis. Jurnal Fiqh, 7, 2948.

Suhid. A. (2005). Pemantapan Komponen Akhlak dalam Pendidikan Islam Bagi Menangani Era Globalisasi. Jurnal Kemanusian, volume 3, no. 2, 95-104. 